I. V. Kovalevska, O. A. Ruban, V. O. Grud'ko

National University of Pharmacy

\title{
The spectrophotometric study of thioctic acid solutions to develop the method of its quantitative determination
}

Type II diabetes mellitus is a heterogeneous and multifactorial disease, which develops in the metabolic syndrome and significantly increases the risk of developing complications, such as angiopathy, neuropathy, retinopathy, nephropathy. Therefore, creation of new drugs that will affect all links of pathogenetic mechanism of the disease is presently topical. The main line treatment of the abovementioned pathologies is the use of antioxidant therapy. Antioxidants are important on different "lines of defense": in the extracellular fluid, membrane and the cell cytosol. Thioctic acid belongs to these substances. The analysis of thioctic acid is of some difficulties as it has high propensity for different transformations, first of all, oxidation and polymerization. Therefore, the search of cost-neutral and at the same time rapid and effective methods of drug analysis remains relevant.

Aim. To study the possibility to determine thioctic acid by the spectrophotometric method.

Materials and methods. The object of the study was the substance of thioctic acid. Adsorption spectra of the solutions obtained was recorded on an Evolution 60-S spectrophotometer in the cells with the layer thickness of $10 \mathrm{~mm}$.

Results and discussion. It has been found that the adsorption spectrum of thioctic acid solution in $0.1 \mathrm{M}$ hydrochloric acid solution contains a wide absorption band with the maximum at $334 \mathrm{~nm}$; it can be used to quantify the concentration of thioctic acid solutions by the method of one-component one-wave spectrophotometry according to the method of standard.

Conclusions. The study conducted shows the possibility to quantify the concentration of thioctic acid solutions in solutions of hydrochloric acid that model the acidic medium of the gastric juice by the method of one-component onewave spectrophotometry according to the method of standard in the maximum at $334 \mathrm{~nm}$.

Key words: thioctic acid; spectrophotometric analysis; diabetes; quantitative determination

\section{І. В. Ковалевська, О. А. Рубан, В. О. Грудько}

\section{Спектрофоотометричне дослідження розчинів тіоктової кислоти з метою розробки методики її кількісного визначення}

Цукровий діабет II типу є гетерогенним та багатофакторним захворюванням, яке розвивається в надрах метаболічного синдрому і значно підвищує ризик розвитку ускладнень, таких як ангіопатія, нейропатія, ретинопатія і нефропатія. Тому актуальним є створення нових препаратів, які чинитимуть вплив на всі ланки патогенетичного механізму захворювання. Основним напрямком лікування зазначених патології є застосування антиоксидантної терапії. Антиоксиданти необхідні на різних «лініях захисту»: в позаклітинній рідині, на мембрані і в цитозолі клітини. До таких речовин відносять тіоктову кислоту. Аналіз тіоктової кислоти становить певні труднощі в силу ії̈ високої схильності до різноманітних перетворень, в першу чергу, окиснення і полімеризації. Актуальним залишається пошук не затратних та водночас швидких і ефективних методів аналізу лікарських засобів.

Тому метою даної роботи є вивчення можливості визначення тіоктової кислоти спектрофотометричним методом.

Матеріали та методи. Об'єктом дослідження була субстанція тіоктової кислоти. Адсорбційні спектри отриманих розчинів знімали на спектрофотометрі Evolution 60-S в кюветах з товщиною шару 10 мм.

Результати та їх обговорення. Встановлено, що в адсорбційному спектрі розчину тіоктової кислоти в 0,1 M розчині хлористоводневої кислоти міститься широка похила смуга поглинання з максимумом при 334 нм, що може бути використано для кількісного визначення концентрації розчинів тіоктової кислоти методом однокомпонентної однохвильової спектрофотометрії за методом стандарту.

Висновки. Проведене дослідження показує можливість кількісного визначення концентрації розчинів тіоктової кислоти в розчинах хлористоводневої кислоти, які моделюють кисле середовище шлункового соку методом однокомпонентної однохвильової спектрофотометрії за методом стандарту в максимумі при 334 нм.

Ключові слова: тіоктова кислота; спектрофотометричний аналіз; иукровий діабет; кількісне визначення

И. В. Ковалевская, О. А. Рубан, В. А. Грудько

Спектрофотометрическое исследование растворов тиоктовой кислоты с целью разработки методики ее количественного определения

Сахарный диабет II-типа является гетерогенным и многофакторным заболеванием, которое развивается в недрах метаболического синдрома и значительно повышает риск развития осложнений, таких как ангиопатия, нейропатия, ретинопатия и нефропатия. Поэтому актуальным является создание новых препаратов, которые будут иметь влияние на все звенья патогенетического механизма заболевания. Основным направлением лечения указанных патологий является применение антиоксидантной терапии. Антиоксиданты необходимы на различных «линиях защиты»: во внеклеточной жидкости, в мембране и в цитозоле клетки. К таким веществам относят тиоктовую кислоту. Анализ тиоктовой кислоты представляет определенные трудности в силу ее высокой склонности к различным преобразованиям, в первую очередь, окислению и полимеризации. Поэтому актуальным остается поиск не затратных и одновременно быстрых и эффективных методов анализа. 
Целью данной работы является изучение возможности определения тиоктовой кислоты спектрофотометрическим методом.

Материалы и методы. Объектом исследования была субстанция тиоктовой кислоты. Адсорбционные спектры полученных растворов снимали на спектрофотометре Evolution 60-S в кюветах с толщиной слоя 10 мм.

Результаты и их обсуждение. Установлено, что в адсорбционном спектре раствора тиоктовой кислоты в 0,1 М растворе соляной кислоты содержится широкая полоса поглощения с максимумом при 334 нм, что может быть использовано для количественного определения концентрации растворов тиоктовой кислоты методом одноволновой спектрофротометрии по методу стандарта.

Выводы. Проведенное исследование показывает возможность количественного определения концентрации растворов тиоктовой кислоты в растворах соляной кислоты, которые моделируют кислую среду желудочного сока методом однокомпонентной спектрофотометрии по методу стандарта в максимуме при 334 нм.

Ключевые слова: тиоктовая кислота; спектрофотометрический анализ; сахарный диабет; количественное определение

Modern medicine has a wide arsenal of drugs with the metabolic action, but along with the favorable pharmacological action and sufficient degree of clinical efficiency they cause a number of undesirable side reactions.

In this regard, the search of highly efficient drugs that suppress inflammation and have minimal side effects remains relevant. One of the approaches is the search for such agents among drugs of the metabolic type action. Being a coenzyme of cocarboxylase and an important participant in the process of biological oxidation in the metabolism of lipids and carbohydrates, thioctic acid belongs to substances of this series. It is used as a hepatoprotector in the treatment of diabetic neuropathy, arteriosclerosis, intoxication. One of the interesting properties of thioctic acid is its antioxidant activity. It is known that the antioxidant system of the body regulates the intensity of free radical oxidation of lipids of cellular membranes. The weakening of the antioxidant protection leads to accumulation of underoxidized metabolites, it causes degradation of membrane structures, inflammation, aging and may result in appearance of tumors [1,2].

It has been shown that many antioxidants usually have the anti-inflammatory properties (vitamin E, ascorbic acid, mexidol, dimephosphon, etc.) However, having a high safety most of them are inferior to NSAIDs by their effectiveness. Unlike other antioxidants thioctic acid and its restored form (dihydrolipoic acid) promote regeneration of oxidized endogenous antioxidants, providing a powerful support for the work of other antioxidant parts of the body [3]. However, there is a limited number of domestic drugs with thioctic acid at the Ukrainian market, indicating the expediency of their creation. To assess the effectiveness of technological developments of new medicines it is necessary to study the release of the active ingredient from the composition of the experimental samples of a drug form. For this purpose it is necessary to develop a method for quantitative determination of the substance studied.

The analysis of thioctic acid has certain difficulties due to its high propensity to a variety of changes, first of all, oxidation and polymerization. Today, there are a lot of methods to quantify thioctic acids, such as high performance liquid chromatography (HPLC), electrochemical, gravimetric, polarographic, spectrometric, and fluorescent methods of analysis. The State Pharmacopoeia of
Ukraine (SPhU) offers quantitative determination using HPLC with an electrochemical detector. The electrochemical detector application allows identifying simultaneously different chemical forms of thioctic acid both oxidized and restored ones. This method is highly sensitive to the presence of impurities, their potential of reduction is close to the potential of thioctic acid reduction, and it causes difficulties in interpreting the results of analysis $[4,5]$.

The search of cost-neutral and at the same time rapid and effective methods of drug analysis is still relevant. These are, in particular, optical methods of analysis that are most popular because of relative simplicity of equipment, high accuracy and sensitivity. The difficulty to determine thioctic acid is that acid molecule does not contain the most common chromophore or fluorescent groups. Therefore, the aim of this work is to study the possibility to determine thioctic acid by the spectrophotometric method.

\section{Materials and methods}

The object of the study was the substance of thioctic acid. The sample of this acid was dissolved in $96 \%$ ethanol (first dilution), the necessary aliquot was diluted with water and $0.1 \mathrm{M}$ solutions of hydrochloric acid or sodium hydroxide. Adsorption spectra of the solutions obtained was recorded on an Evolution 60-S spectrophotometer in the cells with the layer thickness of $10 \mathrm{~mm}$.

The study of oxidation on the spectral characteristics of thioctic acid was conducted by interaction of its solutions with an excess of salt monopotassium solution of peroxymonosulfuric acid (Caro acid) in borate buffer solution with $\mathrm{pH} 9.5$.

\section{Results and discussion}

Thioctic ( $\alpha$-lipoic) acid - 1, 2-dithiolane-3-pentanoic acid (Scheme).

The structure of thioctic acid has no such common chromophores as aromatic or heteroaromatic cycles, but the presence of the carboxyl group and 1,2-ditiolan cycle containing lone-pair electrons suggests that the compound

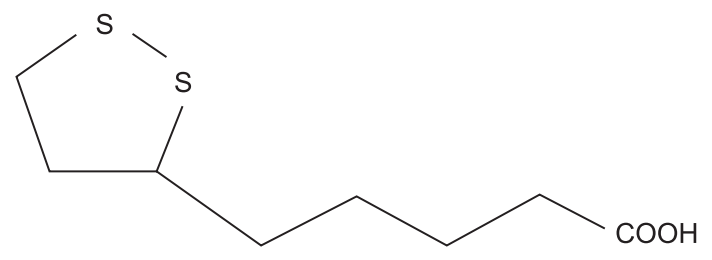




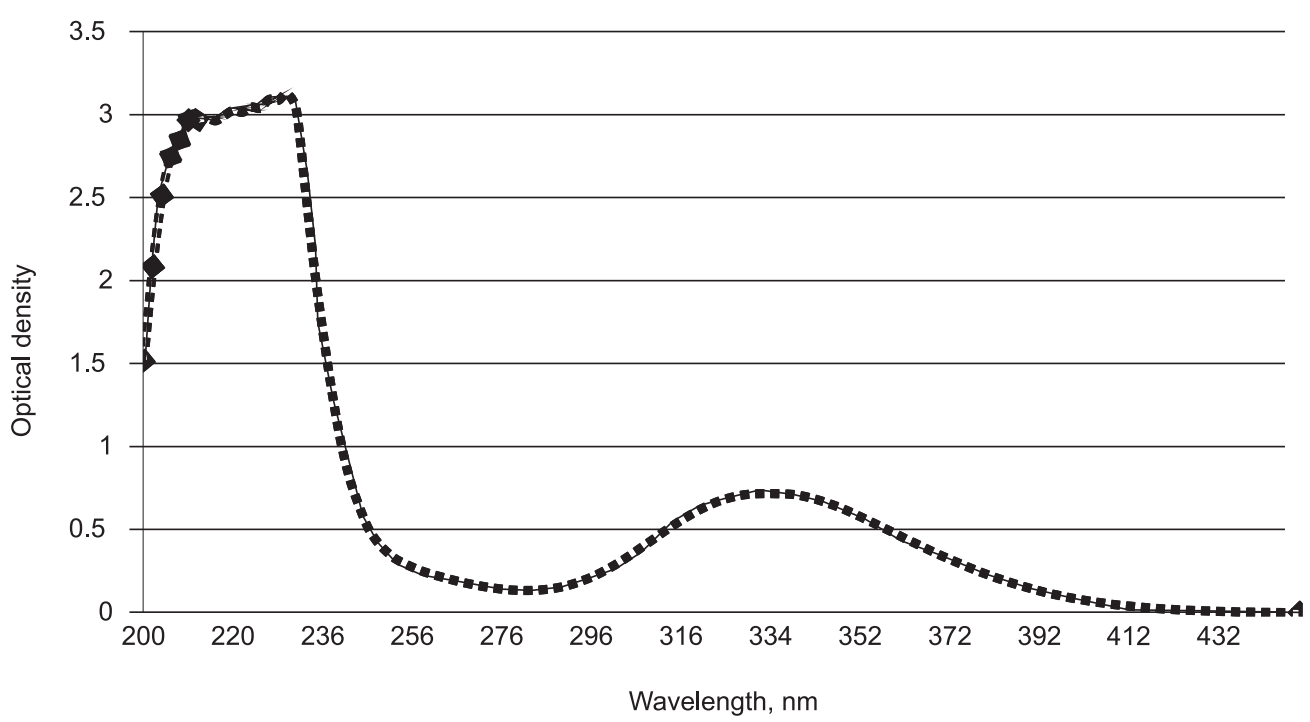

Fig. 1. The adsorption spectrum of $0.1 \%$ thioctic acid solution in ethanol

will be non-transparent for ultraviolet light and, therefore, development of the spectrophotometric method for quantitative determination of thioctic acid in solutions is possible.

The range of $0.1 \%$ alcoholic solution of thioctic acid is characterized by two absorption bands. A wide high intensity band of absorption in the far ultraviolet region at $200-240 \mathrm{~nm}$ is characteristic for many organic substances of both natural and synthetic origin, which contain functional groups with lone-pair electrons in their structure (Fig. 1). In our case, we can assume that the basis of absorption is electronic transitions in the carboxyl group. Thioctic acid solutions are of a pale yellow-green color. In the adsorption spectrum it is illustrated by the presence of a wide, but not very intense absorption band in the near ultraviolet with the maximum at $332-335 \mathrm{~nm}\left(K_{\max } 334 \mathrm{~nm}\right)$ due to the presence of the disulfide bond in the 1,2-dithiolane cycle in its structure.
After dilution of the alcoholic solution with water the adsorption spectrum of $0.05 \%$ alcoholic-water solution of thioctic acid (Fig. 2) is also characterized by two absorption bands in the far and the near ultraviolet; their position is virtually unchanged, however, in the near ultraviolet there is an unusual hypochromic effect since the optical density of this solution decreases more than twice in the process of double dilution of the solution with water. The expansion of the absorption band in the near ultraviolet to $330-338 \mathrm{~nm}$ can be noted.

After dilution of the alcoholic solution of $0.1 \mathrm{M} \mathrm{HCl}$ the adsorption spectrum of $0.05 \%$ thioctic acid solution in the alcoholic-water solution of hydrochloric acid is almost identical with the range of the alcoholic-water solution of the similar concentration (Fig. 2), indicating the absence of protonation of any functional groups.

The change of the reaction medium to the alkaline one alters the nature of thioctic acid absorption only in the distant ultraviolet radiation (Fig. 3).

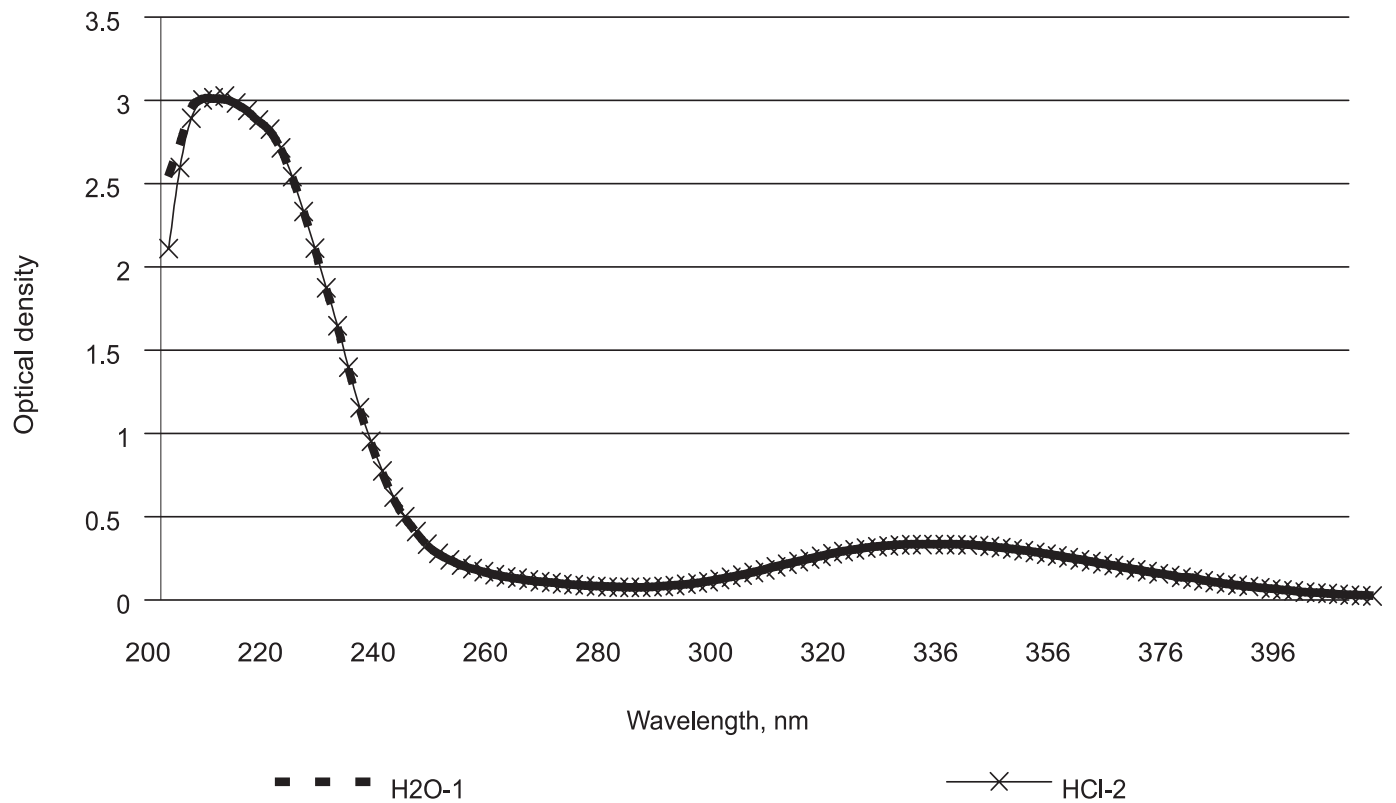

Fig. 2. The adsorption spectrum of $0.05 \%$ thioctic acid solutions in the neutral and acid media 


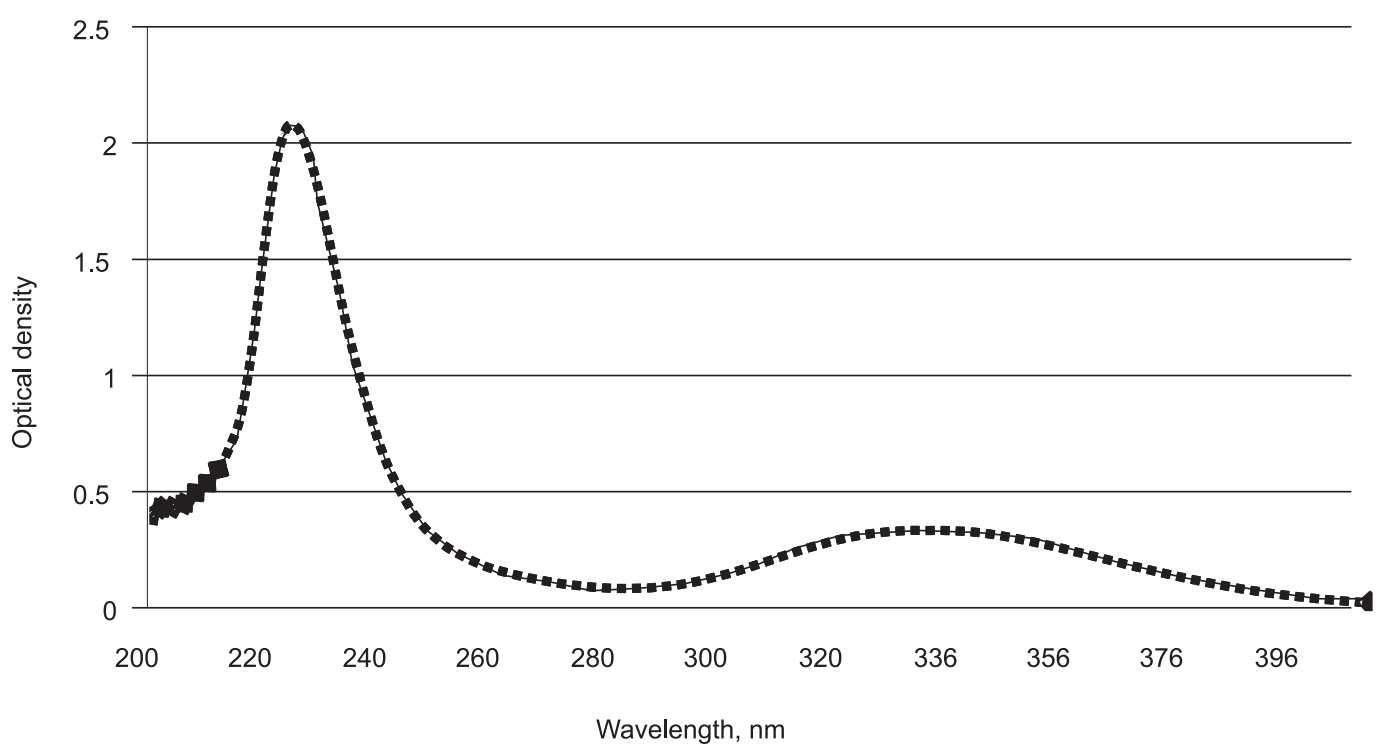

Fig. 3. The adsorption spectrum of thioctic acid solution in the alcoholic-water solution of sodium hydroxide

After dilution of the alcoholic solution with $0.1 \mathrm{M}$ sodium hydroxide solution the adsorption spectrum of $0.05 \%$ solution of thioctic acid in the alcoholic-water solution of sodium hydroxide is characterized by the intense absorption band in the range of 215-240 $\mathrm{nm}$ with a distinct narrow maximum at $225 \mathrm{~nm}$. Thus, the intensity of the absorption band is reduced by approximately $30 \%$ compared to the wide band in the neutral and acid media. The 1,2-dithiolane cycle is isolated from the electronic impact of the carboxyl group by four methylene groups; therefore, the absorption band in the near ultraviolet by its position and intensity corresponds to a similar band in the absorption spectra of solutions with the similar concentration in the neutral and acid media.

It is known that thioderivatives show reducing properties and have the ability to oxidize. In order to study the effect of oxidation on the adsorption spectrum of the substance the interaction of thioctic acid solution with the excess of the monopotassium salt of peroxymonosulfuric acid (Caro acid) was performed. The reaction was carried out in the medium of borate buffer with $\mathrm{pH} 9.5$. The solution of the monopotassium salt of peroxymonosulfuric acid was added to the alcoholic solution of thioctic acid, diluted to the volume by the buffer solution, kept for $20 \mathrm{~min}$, and the adsorption spectrum was registered in relation to the control solution with the corresponding composition.

The nature of the adsorption spectrum of the oxidation products of thioctic acid obtained changes (Fig. 4). As the solution is alkaline, the absorption band in the distant ultraviolet becomes narrower, less intense and has a marked maximum at $215 \mathrm{~nm}$. The absorption band in the near ultraviolet disappears at all. Instead, there is an intense absorption band in the range of 230-250 nm with a wide flat maximum at $243 \mathrm{~nm}$, its presence can be explained by formation of oxidation products - sul-

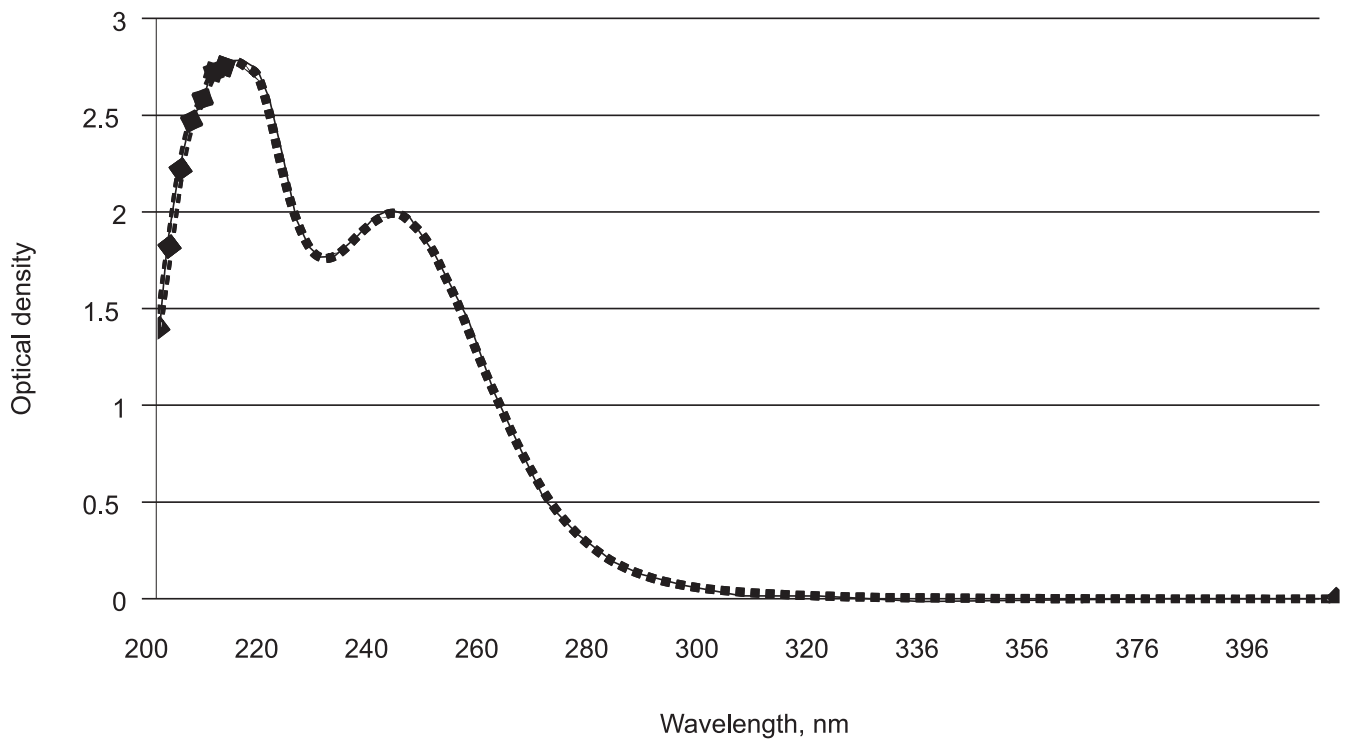

Fig. 4. The adsorption spectrum of dilution of thioctic acid oxidation products with the monopotassium salt of peroxymonosulfuric acid in the buffer solution medium with $\mathrm{pH} 9.5$ 
A

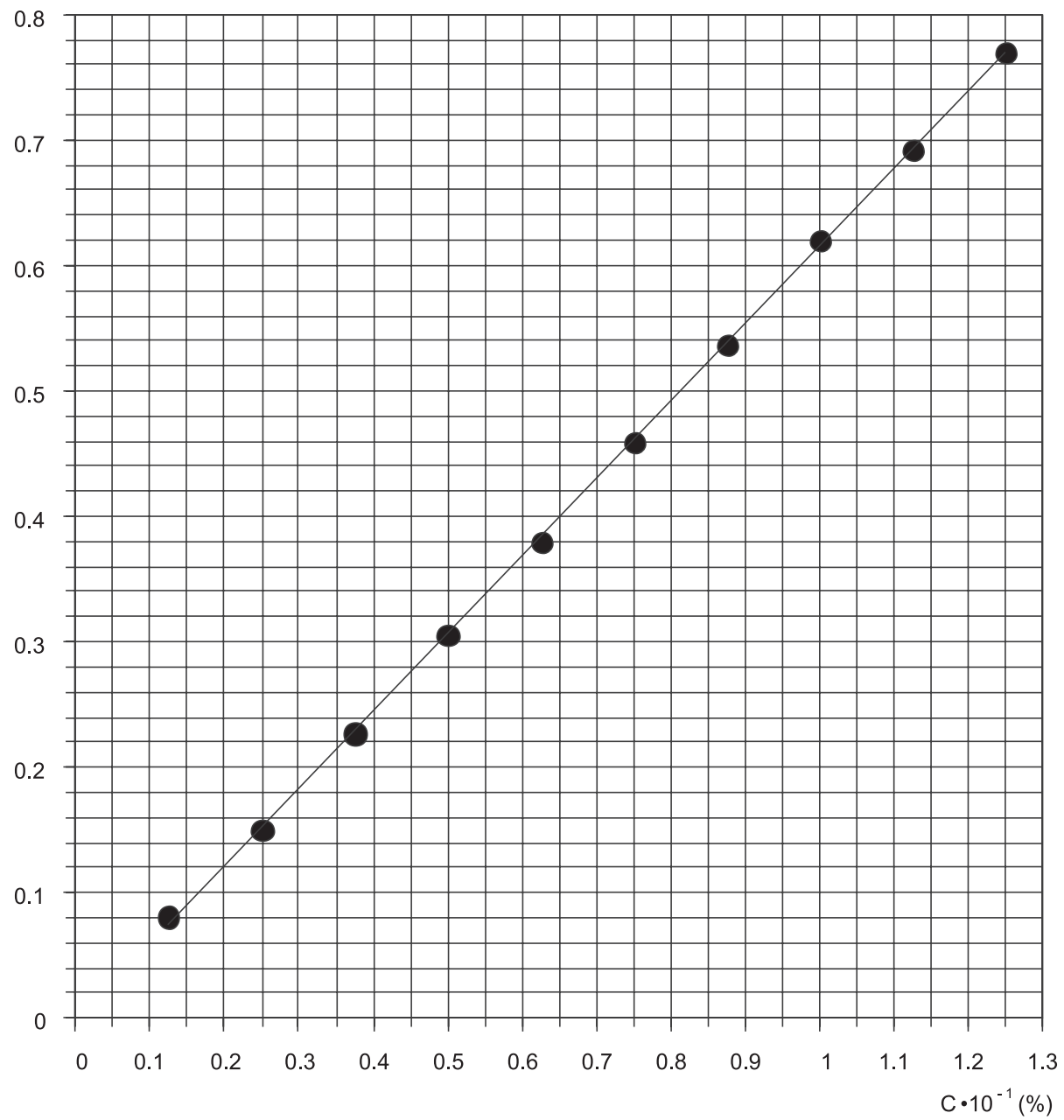

Fig. 5. The calibration graph of dependence of thioctic acid solutions in $0.1 \mathrm{M}$ solution of hydrochloric acid on their concentration

fones or sulfoxides. The absence of absorption in the range of 330-338 $\mathrm{nm}$ indicates that oxidation products of thioctic acid do not prevent its possible quantitative determination using the spectrophotometric method by the absorption band with the maximum at $334 \mathrm{~nm}$, which increases the specificity of analysis.

Thus, our spectral studies have shown that the adsorption spectra of thioctic acid solutions, in particular in $0.1 \mathrm{M}$ solution of hydrochloric acid, contain a broad sloping absorption band with the maximum at $334 \mathrm{~nm}$, which can be used to quantify the concentration of thioctic acid solutions by the method of one-component one-wave spectrophotometry according to the method of standard.

It is known that one of the main conditions of the possibility to use the spectrophotometric method for quantitative determination is subordination of light absorption of the solutions analyzed to Beer-Lambert law. Deviations from the direct subordination of Beer-Lambert law can be caused by solvation, association, dissociation and complexation, which can occur in solutions, especially with increasing their concentration.

The check of Beer-Lambert law application is to construct a graph of dependence of the optical density on the concentration of the solution expressed one or another way.
Light absorption of solutions obeys Beer-Lambert law only within the concentrations, in which the optical density depends directly proportional on the concentration of the solution, and the calibration curve is a straight line (Fig. 5).

The specific absorption rate

$$
A_{1 \mathrm{~cm}}^{1 \%}=\frac{1}{c \cdot b} \cdot A
$$

is constant in the same range (taking into account some deviations caused by dispersion of solution preparation).

The results of checking subordination for light absorption of thioctic acid solutions in $0.1 \mathrm{M}$ solution of hydrochloric acid according to Beer-Lambert law are presented in Table and Fig. 5.

The analysis of the experimental data obtained shows that light absorption of thioctic acid solutions in $0.1 \mathrm{M}$ solution of hydrochloric acid is linear and obeys BeerLambert law within the whole range of the concentrations studied from 1.25 to $12.50 \cdot 10-2 \%$. The intensity of absorption is sufficiently low; the specific absorption rate is only $6.148 \pm 0.106$.

The presence of rectilinear dependence between the concentration and optical density suggests the possibility of determining the concentration of thioctic acid 
Table

The results of checking subordination for light absorption of thioctic acid solutions in $0.1 \mathrm{M}$ solution of hydrochloric acid according to Beer-Lambert law

\begin{tabular}{|c|c|c|c|c|c|c|c|c|c|c|}
\hline No. & 1 & 2 & 3 & 4 & 5 & 6 & 7 & 8 & 9 & 10 \\
\hline $\mathrm{x} \cdot 10^{-2}, \%$ & 1.25 & 2.50 & 3.75 & 5.00 & 6.25 & 7.50 & 8.75 & 10.00 & 11.25 & 12.50 \\
\hline $\mathrm{A}$ & 0.081 & 0.150 & 0.227 & 0.305 & 0.380 & 0.459 & 0.537 & 0.620 & 0.692 & 0.770 \\
\hline$A_{1 \mathrm{~cm}}^{1 \%}$ & 6.48 & 6.00 & 6.05 & 6.10 & 6.08 & 6.12 & 6.14 & 6.20 & 6.15 & 6.16 \\
\hline
\end{tabular}

solutions in $0.1 \mathrm{M}$ solution of hydrochloric acid by the method of one-component one-wave spectrophotometry with further calculation of the concentration according to the method of standard.

\section{CONCLUSIONS}

1. In order to develop the spectrophotometric method for determining the concentration of solutions of thioctic acid to study its bioavailability as part of the dosage forms the research of the adsorption spectra of thioctic acid solutions in different media has been conducted. It has been found that the adsorption spectrum of thioctic acid solution in $0.1 \mathrm{M}$ solution of hydrochloric acid contains a broad sloping absorption band with the maximum at $334 \mathrm{~nm}$, which can be used to quantify the concentration of thioctic acid solutions by the method of one-component one-wave spectrophotometry according to the method of standard.

2 . The study of the adsorption spectra of the solution of thioctic acid oxidation products with the monopotassium salt of peroxymonosulfuric acid has shown that they do not absorb ultraviolet radiation in the range of $334 \mathrm{~nm}$; therefore, oxidative degradation products do not distort the results of spectrophotometric quantitative determination of thioctic acid by the absorption maximum at $334 \mathrm{~nm}$.

3. In order to determine the limits of subordination of light absorption of thioctic acid solutions to Beer-Lambert law the calibration graph of dependence of the optical density of the solutions on the concentration has been built. It has been found that light absorption of thioctic acid solutions in $0.1 \mathrm{M}$ solution of hydrochloric acid in the maximum at $334 \mathrm{~nm}$ is linear and obeys BeerLambert law within the whole range of the concentrations studied from 1.25 to $12.50 \cdot 10^{-2} \%$. The intensity of absorption is rather low, and the specific absorption rate is only $6.148 \pm 0.106$.

4. The study conducted shows the possibility to quantify the concentration of thioctic acid solutions in solutions of hydrochloric acid that model the acidic medium of the gastric juice by the method of one-component onewave spectrophotometry according to the method of standard in the maximum at $334 \mathrm{~nm}$.

Conflict of Interests: authors have no conflict of interests to declare.

\section{REFERENCES}

1. Bajaj, S. Antioxidants and diabetes / S. Bajaj, A. Khan // Indian J. of Endocrinol. and Metabolism. - 2012. - Vol. 16. - P. $267-271$.

2. Bilska, A. Lipoic acid - the drug of the future? / A. Bilska, L. Wtodek // Pharmacol. Reports. - 2005. - Vol. 57. - P. $570-577$.

3. Rajkumar, B. Reverse Phase HPLC Method Development and Validation for the Simultaneous Quantitative Estimation of Alpha Lipoic acid and Allopurinol in tablets / B. Rajkumar, T. Bhavya, A. Ashok Kumar // Intern. J. of Pharmacy and Pharmac. Sci. - 2014. - Vol. 6, Issue 1. - P. 307-312.

4. Evans, J. L. A-Lipoic Acid : A Multifunctional Antioxidant That Improves Insulin Sensitivity in Patients with Type 2 Diabetes / J. L. Evans, I. D. Goldfine // Diabetes Technol. \& Therapeutics. - 2000. - Vol. 2, Issue 3. - P. 401-413. doi: 10.1089/15209150050194279

5. Patel, D. J. Development and Validation of Spectroscopic Method for Simultaneous Estimation of Allopurinol and $\alpha-$ Lipoic Acid in Combination Tablet / D. J. Patel, V. C. Jain, H. A. Raj // Res. and Reviews : J. of Pharmac. Analysis. - 2014. - Vol. 3, Issue 3. - P. $28-36$.

\section{REFERENCES}

1. Bajaj, S., Khan, A. (2012). Antioxidants and diabetes. Indian Journal of Endocrinology and Metabolism, 16, $267-271$.

2. Bilska A, Wtodek, L. (2005). Lipoic acid - the drug of the future? Pharmacological Reports, 57, 570-577.

3. Rajkumar, B., Bhavya, T., Ashok Kumar, A. (2014). Reverse Phase HPLC Method Development and Validation for the Simultaneous Quantitative Estimation of Alpha Lipoic acid and Allopurinol in tablets. International Journal of Pharmacy and Pharmaceutical Sciences, 6 (1), 307-312.

4. Evans, J. L., Goldfine, I. D. (2000). $\alpha$-Lipoic Acid: A Multifunctional Antioxidant That Improves Insulin Sensitivity in Patients with Type 2 Diabetes. Diabetes Technology \& Therapeutics, 2 (3), 401-413. doi: 10.1089/15209150050194279

5. Patel, D. J., Jain, V. C., Raj, H. A. (2014). Development and Validation of Spectroscopic Method for Simultaneous Estimation of A1lopurinol and $\alpha$-Lipoic Acid in Combination Tablet. Research and Reviews: Journal of Pharmaceutical Analysis, 3 (3), $28-36$. 


\section{Information about authors:}

Ruban O. A., Doctor of Pharmacy (Dr. habil), professor, head of the Department of Industrial Technology of Drugs, National University of Pharmacy.

ORCID: http://orcid.org/0000-0002-2456-8210

Kovalevska I. V. Candidate of Pharmacy (Ph. D), associate professor of the Department of Industrial Technology of Drugs, National University of Pharmacy.

E-mail: inga.kovalevskaya@gmail.com. ORCID: http://orcid.org/0000-0001-5610-8334

Grud'ko V. O., Candidate of Chemistry (Ph. D), associate professor of the Department of Pharmaceutical Chemistry, National University of Pharmacy

Відомості про авторів:

Рубан О. А., д-р фарм. наук, професор, завідувач кафедри заводської технології ліків, Національний фармацевтичний університет.

ORCID: http://orcid.org/0000-0002-2456-8210

Ковалевська I. В., канд. фарм. наук, доцент кафедри заводської технології ліків, Національний фармацевтичний університет.

E-mail: inga.kovalevskaya@gmail.com. ORCID: http://orcid.org/0000-0001-5610-8334

Грудько В. О., канд. хім. наук, доцент кафедри фармацевтичної хімії, Національний фармацевтичний університет

Сведения об авторах:

Рубан Е. А., д-р фарм. наук, профессор, заведующая кафедрой заводской технологии лекарств, Национальный фармацевтический университет

ORCID: http://orcid.org/0000-0002-2456-8210

Ковалевская И. В., канд. фарм. наук, доцент кафедры заводской технологии лекарств, Национальный фармацевтический университет.

E-mail: inga.kovalevskaya@gmail.com. ORCID: http://orcid.org/0000-0001-5610-8334

Грудько В. А., канд. хим. наук, доцент кафедры фармацевтической химии, Национальный фармацевтический университет 